\title{
Responsibility and Task Structuring as the Basic Attributes of Learning Styles and Their Relation Towards Consistency and the Quality of Hierarchy of a Learner's Mind Map
}

\section{Jana Duchovičová - Nina Kozárová*}

\begin{abstract}
The study focuses on the identification of the relationship between the learning style and mental representation of curriculum content. The research problem identifies the relationship between the learning style factors - responsibility and task structuring and the selected categories of curriculum content representation - consistency and the quality of hierarchy identified through mind mapping. For the purposes of the research, we used the LSI Questionnaire by R. Dunn, K. Dunn and G. E. Price, a mind mapping test and chi-square statistics were used for the evaluation of research findings. The research sample consisted of 115 respondents. By means of analysis, we found out that a learning style in the observed factors of responsibility and task structuring does not influence students' mental representation of the curriculum content.

Key words: learning style, mind map, mental representation of curriculum content, semantic net, text structuring, responsibility, task structuring.
\end{abstract}

\section{Introduction}

The efficiency of the educational process belongs to one of the most discussed issues of the educational reality. It has been a matter of interest of pedagogical and psychological scientific communities as well as professional and lay public represented by teachers and students' parents. We suppose that the implementation of psycho-didactic knowledge on learning styles and methodology of mind mapping can contribute towards a quality increase and the effectiveness of education. A number of studies carried out within the last twenty years with the attempt to reveal learning mechanisms and the structure of thinking have become the sources of the latest knowledge on optimization of

Jana Duchovičová, Constantine the Philosopher University in Nitra, Faculty of Education, Department of Pedagogy, Nitra, Slovakia; jduchovicova@ukf.sk

Nina Kozárová, Constantine the Philosopher University in Nitra, Faculty of Education, Department of Pedagogy, Nitra, Slovakia; nina.kozarova@ukf.sk 


\section{Acta Technologica Dubnicae \\ volume 6, 2016, issue 2}

education and learning strategies. The thesis by Thagard (2001, p. 25), that thinking is comprehensible mostly in meaning representing mind structures in the concepts of computing procedures operating on these structures (so-called computing-representation mind assumption - CRUM) contributed towards a vast development of cognitive science as well as neuro- and psycho-didactics, which focus their research attempts towards the operations with mind content and mental representations as subjective, inner ideas about outer realities, existing within a learner's mind.

Logic thinking principles with the stress on inference rules applying to the collection of premises are the main interests of cognitive science. "If-then" structures are also significant because if we operate with rules we do not use logical deduction but an overview of possibilities. Professionals state that some rules may be innate; however, most of them are the results of inductive generalization or specification - modification of existing rules according to the particular situation. The focus is on concepts, their conduction, creation of mind systems, semantic nets, the way we understand and learn the content of concepts, cognitive grammar, validity of prototype and classical application of concepts, and the extent to which the basic ideas on concepts and the ability to create the new concepts are innate (more in Duchovičová, 2010).

However, the ways of concept representation in the brain are still mysterious. Thagard (2001, p. 92) summarizes that concepts representing words of spoken and written language form an essential type of mental representations but the idea that every concept is clearly defined may be rejected and the concepts may be viewed as sets of typical qualities as using concepts lies in the acquisition of approximate correspondence between concepts and the world. Mind map structures have been dealt with by e.g. Kosslyn (1994), Glasgow and Papadias (1992), as well as Wong, Lu and Rioux (1989).

Social constructivism represented by Vygotsky has significantly contributed towards the explanation of the relationship between the mental structure and the social cultural environment. In didactics, cognitivism contributed to the origins of developmental education, learning with support (Zankova, Elkonina, \& Davydova) theory of meaningful learning (Ausubel, 1967) based on the theory of cognitive development (Bruner, 1965), and the theory of prior knowledge (Dochy, 1992, 1996).

Following significant psychological and didactic action, our ambition is to contribute to the cognitive knowledge by means of a research carried out in the field of learning style preference in relation to the representation of curriculum content shown in a representation scheme "mind map". Based on the fact that our educational activity should help the children's orientation; it should 


\section{Acta Technologica Dubnicae \\ volume 6, 2016, issue 2}

contribute to the organization of thinking and terminology used by them. Human knowledge is based on a solid base, $i$ tis a semantic map (net) interconnecting the acquired notions (acquiring a notion represents creating an idea about its content).

A specific kind of elaborating mental concepts is to interconnect notions which we are already familiar with. Fischer $(2004$, p. 72$)$ points out that creating concepts starts with remembering new words and their categorizing into an existing net of knowledge - thus a new form of comprehension starts. However, we categorize notions, not sentences. This is a mistake of many teachers. When recalling some information, we very rarely proceed word by word - we do not read from our memory (that would be a demanding and a long-term procedure). We can retrieve memories only due to the fact that we recall key words and images and we build up the utterances.

Transmission of the curriculum content in schools either by a teacher or textbooks is mostly linear and contains certain, as Ausubel (1967) calls them, advance organizers. These are mainly the introductory parts of a thematic field regulating the further advance of a student having a balancing function (activating the studnet's prior knowledge in order to have something to build on) and an explanatory function (providing the student with new knowledge which is essential for understanding further content). Organizers enable gaining a certain overview. A student, though, has to cover also certain relations among the notions - the whole semantic relation net. This one is usually not explicitly included in the teacher's presentation nor the textbook, it is covered implicitly. The learners thus have to fully concentrate and find the relations among the notions by themselves (they can read written texts several times but they cannot listen to the same spoken utterance again). The notions and the identified relations have to be extracted from the original text and built up in a more accurate way by the student: it is necessary to construct their structure. Teachers and textbook authors presume that learners are able to do these actions, however, nobody teaches them how to do so, even though it is an essential part of their learning style. Teachers underestimate this psycho-didactic aspect. Students' skill of text structuring is only developed by trial and error and, therefore, the identification of the text structure is often not correct or incomplete. Sometimes, the whole text structure is presented by the teacher and the sudents passively memorize it in order to be able to reproduce it.

In the end of the 1960s, researchers started to focus on searching for the methods of teaching students to structure the curriculum. The concept of the orienting basis of activity by a Russian psychologist Galperin (1980) and the schematic concept (a specific procedure also called "hand-out") belong to the older theories of curriculum structuring. More modern approaches to curriculum structuring 


\section{Acta Technologica Dubnicae \\ volume 6, 2016, issue 2}

were developing in the $70 \mathrm{~s}-90 \mathrm{~s}$ based on the theory of semantic memory, theory of learning strategies, theory of information processing with the aim to improve the strategies of thinking. Knowledge on symbolic memory has led to the idea that processing and storing information can be conveyed hierarchically by an organized system of schemes and sub-schemes. As stated by Mareš (2001), the theory on graphs was elaborated later on. Based on that, it is possible to develop complex relations as well as richly structured networks. It is mainly about deep elaboration from up to down or bottom to up, and by reorganization. If a student is to learn the curriculum content, then it is convenient to have it organized before learning. By an increasing number of variations of coding, the number of possible key searches, and thus the probability of correct recall from the memory, increases. Non-linear abstract representations of curriculum structure are based on the idea of organizing key notions and relations as clearly as possible, visualizing them and drafting an easily accessible, abstract „external memory."

Nowadays, there are many different types of graphical displays with different names, however, the term "mind map" is used to label various methods and techniques. The issues of mind maps and non-linear schematic display were introduced into pedagogy by Dansereau et al. in 1970 and, later on, his theory was broadened by further research (see Bahr \& Dansereau, 2004).

The use of mental schemes and mapping seems is the first step towards the improvement of critical and creative thinking; therefore, this issue is in the centre of attention of our study. Our focus has been narrowed to the didactics of a selected subject.

\section{Mind maps}

The life in modern democracy tends to remove ignorance. It is generally known that the worst thing is to remember isolated knowledge without any logical connection and which one is not able to associate with other curriculum content. These aspects are a prototype for teaching history.

Buzan (2011, p. 41) characterizes a mind map as follows, "A mind map is a picture expression of beam thinking. It is a process within which the human brain thinks and comes up with ideas. When we catch and illustrate them, we create a mind map, an outer mirror reflecting the actions going on in our heads". Thanks to a mind map, new and prior knowledge are sorted naturally. Moreover, when creating a mind map, people use both the hemispheres. The left hemisphere is engaged due to logical organization, words, notions and numbers. The right hemisphere due to imagination and visualisation. Thus, engaging both 


\section{Acta Technologica Dubnicae \\ volume 6, 2016, issue 2}

hemispheres contributes to easier remembering of the content and to more effective learning.

A mind map is developed in a simple way. A key word is written in the middle of a blank sheet of paper. Later on, the notions associated with the key word the main topic, are written around and linked together - individual branches. The aim of mind mapping is to create a certain structure of notions - a semantic net. This structure can help students find out and verify the logical coherence of their individual interpretation of the selected thematic field.

According to Hubatka (2010), there is a vast number of possibilities of how to use mind mapping in the classroom. It can be finding the key notions in a thematic field, a form of taking notes, a method for helping a teacher create a meaningful structure of the curriculum content, a form of group or individual work, a new way of structuring the curriculum content, stopping memorizing by students and developing learning with comprehension. Maps also make memorizing, reconstructing and retrieving the content easier. It is impossible to comprehend the way in which our students think, the way they learn and remember things, if teachers keep explaining a topic in front of the class for 45 minutes. We have to provide students with space to express themselves. If we show them how to comprehend, think critically, analyse in a broader sense, we can help them in their lives.

Consistency and the quality of hierarchies of a learner's mind map are the focused constructs in our study.

We have found resources for the evaluation of students' mental maps in the works by Daley (2004), Swan (1997), Bahr (2004), Perusich (2010), etc. Mind maps can be evaluated in two ways. The first lays in visual assessment by which we are able to identify the absence of certain notions. The second method is called "scoring" which is based on certain criteria that can be adapted by the researcher in order to work with the statistical data in the most suitable way. As for operationalization, the quality of hierarchies is related to the levels of relationships, some kind of connection between higher and lower order notions which are mutually interconnected. A map consists of main knots (points), for illustration of which any geometrical shapes may be used. The most essential, however, is information written inside the geometrical shapes. Learners can express the relations among information by using hierarchy for the topic organized in the mind map. The quality of hierarchy is thus understood as the level on which the notions are connected into the hierarchy.

Another parameter of operationalization is the consistency of a mind map. Under that notion we understand the quality of the mind map created by a student. We 


\section{Acta Technologica Dubnicae \\ volume 6, 2016, issue 2}

set the following criteria of consistency: mapping the curriculum content by the student is only elementary, the student's overall insight into the curriculum content presented in the mind map, whether the mind map covers actual but also prior topics/contents, the number of illustrated relationships and the overall image of the mind map.

\section{Learning style}

For the purposes of the study, it is necessary to give an illustration overview of the levels which we can encounter when working with the concept of learning style. The first aspect is the interpretation framework which refers to relevant theories or their more modern adaptations helping to increase the significance of various learning styles as well as of the research on particular mental processes. The application framework which tries to show the practical point of using learning styles in the teaching process and also for the fields of diagnostics, methodological and research procedures, can be considered to be the second aspect. The aim and the common motive of interpretation and application framework is an attempt to overcome the possible deficiencies of teaching and to offer a richer and a more effective way of instruction.

The issues of learning styles have been researched on for more than forty years and they are dealt with in Slovak literature in studies and scholarly articles as, for example, by Turek (2002), Kaliská (2008, 2009), Zat'ková (2011), Riding and Rayner (2009,) etc. Learning styles are mostly defined as procedures used by learning which are preferred by an individual in a particular period of time (Fenyvesiová, 2006, p. 69).

Mareš $(1998$, p. 75) characterizes a learning style as a collection of procedures preferred by an individual in a certain period of life. It is a specific way of learning used by a learner in different learning situations whereby these procedures are not stable and they can vary throughout the learnr's life.

If students recognize their strengths and weeknesses in the learning process, they can choose the most effective procedures in which they can achieve the most effective results. Therefore, every person can create a system of behaviour for the learning process which seems to be the most effective. It is the learning style which differs with every person by its structure, quality but also the way of application or flexibility.

We agree with Tassel (2010), who considers an individual learning style to be a sum of methods of gaining information and various reactions in life situations. The learning style, according to the author, reflects the emotional reactions of a person, attitudes, habits and preferences. By recognizing their learning styles, we 


\section{Acta Technologica Dubnicae \\ volume 6, 2016, issue 2}

can communicate with students easier, to suggest and store inputs from the environment. Riding and Rayner (2009, p. 51) divide learning styles into three categories based on the similarities in the psychometric scheme, in understanding the notion of learning but also in relation to developing a learning strategy. These authors consider the learning style a unique set of differences which cover one's personal preferences in the educational process, the form of educational activity, and the differences in personal and intellectual fields. The classification represented by these authors is divided into groups of models of learning styles based on:

- learning processes - on experience and empirical learning,

- learning processes - on study orientation,

- preference of instruction,

- development of cognitive skills and learning strategies.

\begin{tabular}{|c|c|c|}
\hline Dimension & Description & Reference \\
\hline \multicolumn{3}{|l|}{ Models based on learning process } \\
\hline $\begin{array}{l}\text { Particular experience/reflecting } \\
\text { observation/abstract comprehension } \\
\text { of notions/active experimenting }\end{array}$ & $\begin{array}{l}\text { Two-dimensional model covering } \\
\text { perception and procession of } \\
\text { information }\end{array}$ & Kolb (1976) \\
\hline $\begin{array}{l}\text { Activists/theoretic/pragmatic/ } \\
\text { reflector }\end{array}$ & $\begin{array}{l}\text { Preferred ways of learning creating } \\
\text { an individual attitude towards } \\
\text { learning }\end{array}$ & $\begin{array}{l}\text { Honey } \\
\text { and Mumford } \\
(1986,1992)\end{array}$ \\
\hline \multicolumn{3}{|c|}{ Models coming out of study orientation } \\
\hline $\begin{array}{l}\text { Orientation on } \\
\text { importance/reproduction/orientation } \\
\text { on performance/holistic orientation; } \\
\text { later on deep, strategic, shallow, } \\
\text { without goals, powerful. }\end{array}$ & $\begin{array}{l}\text { Integration of instruction preference } \\
\text { with processing information in } \\
\text { learner's attitude towards study. }\end{array}$ & $\begin{array}{l}\text { Entwistle } \\
(1979) \\
\text { Entwistle } \\
\text { and Tait } \\
(1994)\end{array}$ \\
\hline $\begin{array}{l}\text { Shallow-deep performance } \\
\text { orientation/inner-outer performance } \\
\text { orientation. }\end{array}$ & $\begin{array}{l}\text { Integration of attitudes towards a } \\
\text { study with motivational orientation. }\end{array}$ & $\begin{array}{l}\text { Biggs (1978, } \\
\text { 1985) }\end{array}$ \\
\hline
\end{tabular}




\begin{tabular}{|c|c|c|}
\hline $\begin{array}{l}\text { Synthesis-analyses/developing } \\
\text { processing/memorizing of facts/study } \\
\text { methods. }\end{array}$ & $\begin{array}{l}\text { Quality of thinking within learning } \\
\text { regarding differences, transfer and } \\
\text { memory and retaining the facts in } \\
\text { the memory. }\end{array}$ & $\begin{array}{l}\text { Schmeck } \\
\text { (1977) }\end{array}$ \\
\hline \multicolumn{3}{|l|}{ Models based on instruction preference } \\
\hline $\begin{array}{l}\text { Elements of } \\
\text { environment/sociological/emotional/ } \\
\text { physical/psychological. }\end{array}$ & $\begin{array}{l}\text { Learner's reactions on key stimuli: } \\
\text { environment, socialization, } \\
\text { emotionality, physicality, } \\
\text { psychology. }\end{array}$ & $\begin{array}{l}\text { Price (1976) } \\
\text { Dunn and } \\
\text { Dunn (1989) }\end{array}$ \\
\hline $\begin{array}{l}\text { Participant- avoiding } \\
\text { Cooperating- } \\
\text { competitive/independent - dependent }\end{array}$ & $\begin{array}{l}\text { Social interaction developing three } \\
\text { bipolar dimensions into a scheme } \\
\text { describing learner's typical approach } \\
\text { towards a learning situation }\end{array}$ & $\begin{array}{l}\text { Grasha and } \\
\text { Riechmann } \\
(1975)\end{array}$ \\
\hline \multicolumn{3}{|c|}{ Models based on development of cognitive skills } \\
\hline $\begin{array}{l}\text { Visualization/verbal } \\
\text { symbols/sounds/feelings. }\end{array}$ & $\begin{array}{l}\text { Learning styles defined based on } \\
\text { a form of perception }\end{array}$ & $\begin{array}{l}\text { Reinert } \\
(1976)\end{array}$ \\
\hline $\begin{array}{l}\text { Dependence on the field/searching - } \\
\text { focus/width of } \\
\text { categorization/cognitive } \\
\text { complexity/impulsiveness/balance - } \\
\text { focusing/(in)tolerance. }\end{array}$ & $\begin{array}{l}\text { Cognitive profile of three learner } \\
\text { types reflecting their position in } \\
\text { bipolar, analytical and global } \\
\text { continuum expressing an individual } \\
\text { development of cognitive skills. }\end{array}$ & Letteri (1980) \\
\hline $\begin{array}{l}\text { Cognitive skills/perception } \\
\text { reactions/preferences at study and } \\
\text { instruction. }\end{array}$ & $\begin{array}{l}\text { Identifies } 24 \text { parts of learning style } \\
\text { collected into three dimensions. The } \\
\text { model assumes that development of } \\
\text { cognitive skills is a condition for } \\
\text { effective learning. }\end{array}$ & $\begin{array}{l}\text { Keefe } \\
\text { and Monk } \\
(1986) \\
\text { Keefe (1989, } \\
1990)\end{array}$ \\
\hline
\end{tabular}

Figure 1. Learning style models by Riding, R. and Rayner, S. (2009) 


\section{Acta Technologica Dubnicae \\ volume 6, 2016, issue 2}

Petlák (2009) accentuates the use of learning styles in school environment and he believes that the importance of their use is underestimated. He points out the fact that students' brain is not a passive organ which works in a way a teacher wants to. It means that knowledge on brain functioning and learning processes helps teachers identify the students' ways of learning and learning strategies and based on that teachers can influence students' learning performance by application of appropriate methods respecting individual peculiarities in the learning process.

Different studies dealing with learning styles meet in opinions when respecting an individual learning style means rejection of traditional presentation of curriculum content by a teacher which increases the number of students engaged in the learning process. According to Lojová (2005, p. 176), an educator should use a wide spectrum of techniques, methods and activities so that students can subconsciously choose only those subjects which enable them to process information in the easiest possible way.

According to research findings, learners with a visual learning style prefer learning in a quiet environment with clear instructions from the teacher and they are the most responsible group when learning. Learners with an auditive learning style are, according to research findings, less responsible when learning and prefer a sound background. Learners with a kinaesthetic learning style are the least responsible and they almost do not need to structure the task given by a teacher.

In the proposed study, we paid attention to the selected components of learning styles, in particular responsibility and task structuring. Therefore, for identification of the level of these constructs, we used the LSI questionnaire of learning style: Learning Style Inventory (Dunn, Dunn, \& Price, 2004). The questionnaire accentuates the preference of some factors influencing learning and being decisive for a learner's learning style. It summarizes the emotional, physical, social and environmental factors preferred by individuals when learning, focusing attention in the educational process, i.e. what makes them different from their peers. The questionnaire consists of 71 questions, in which the authors concentrated on 21 variables. In particular, it is the preference of silence or noise when learning, the need for light and warmth when learning, the qualities of furniture, intrinsic motivation, persistence, responsibility, task structuring, independent learning or learning with friends, the necessity of the presence of an authority when learning, auditive vs. visual learning, tactile learning, need to consume food and drinks when learning, preference of learning in the morning, afternoon or in the evening, changing the place of learning, and extrinsic motivation by parents or teachers. The variable of responsibility is connected with students' effort to do what they consider to be correct. In school 


\section{Acta Technologica Dubnicae \\ volume 6, 2016, issue 2}

environment, the question of responsibility is mostly related to students' attempts to fulfil all the requirements given by their teacher. Students' responsibility is connected with their attempts to satisfy the authority of adults as well as with a responsible attitude towards a given task regardless its difficulty. By means of the second variable "task structuring", our intention was to find out whether students prefer having the description of a task with a detailed definition of the requirements for completing it or they like the possibility of independent work on tasks more. The factor of task structuring represents the bipolarity between whether students need or do not need clear instructions.

\section{Methodology}

\subsection{Research objectives}

The study objective was to find out whether there is a relationship between the learning style of a learner and the mental representation of the curriculum content. The research problem identifies the relationship between the following learning style factors: responsibility and task structuring, and the selected categories of curriculum content representation: consistency and the quality of hierarchy identified through mental mapping.

The following suppositions came out of the stated research problem:

1. We suppose that responsibility as a factor of learning style influences the mental representation reflected in the consistency of a mind map

2. We suppose that task structuring as a factor of learning style influences the mental representation reflected in the quality of hierarchy.

\subsection{Research methods}

In the context of the needs of the formulated research problem, for the purposes of the research we used:

1. LSI questionnaire by Dunn, Dunn and Price (2004) for secondary schools where we carried out our research. We gathered information regarding the individual students' learning process, how they proceed when learning something new or a difficult content by means of LSI questionnaire. The questionnaire contained 71 questions. The acquired data were processed by coding individual items so that it was clear whether a learner either 0 - does not prefer or 1- prefers the particular factor.

2. The method we used for the inquiry on the mental representation of curriculum content was the test of notion mapping. Learners recorded a key word in a blank paper, later the notions, names and dates which were, according to them, connected with the topic or the key word and they linked 


\section{Acta Technologica Dubnicae \\ volume 6, 2016, issue 2}

them by lines. In every classroom, it was a non-structuring way of mind mapping as the learners did not get a list of notions associated with a key word. When evaluating the mind maps, we determined the criteria (quality of hierarchies, consistency of mind maps), which were scored as follows:

- Quality of the hierarchies: the quality represents the level of particular hierarchies which was coded by points from 1 to 5 , one point representing the lowest level and five the highest one. We paid attention to the meaning of the connection between the key notions and the hierarchy, the connection between notions and the importance and meaningfulness of the hierarchy;

- Consistency: Consistency of a mind map was scored by points 1-10. 1 represented the lowest number of points and 10 the highest. We determined particular criteria as for example: the overall visual design, characteristics of the pictured relations, overall insight of a learner into the curriculum content - whether he/she maps only elementary content or tries to use cross curricular relations as well, whether the mind map pictures both prior and the actual curriculum content.

3. The determined field of research focused on a relation research problem; therefore, we used a chi-square test of independence in order to evaluate the findings.

\subsection{Characteristics of the research sample}

The school environment in which the research was carried out was limited to secondary grammar schools. We assumed that students at secondary schools/secondary grammar schools had more stable structures of knowledge; therefore, the mind maps would contain more notions and mutual hierarchies. The research sample covered four classrooms with both boys and girls. Every respondent had the same conditions for filling in the LSI questionnaire as well as for making a mind map of a certain topic. In order to generalize the results, we tried to choose the sample in the most objective way. In total, we chose 115 respondents from 4 school classes.

Table 1

The structure of the research sample

\begin{tabular}{|c|c|cc|}
\hline Class & Total & Girls & Boys \\
\hline 3A & 29 & 20 & 9 \\
\hline 3B & 31 & 23 & 8 \\
\hline 3C & 26 & 11 & 15 \\
\hline 3D & 29 & 13 & 16 \\
\hline
\end{tabular}




\section{Acta Technologica Dubnicae \\ volume 6, 2016, issue 2}
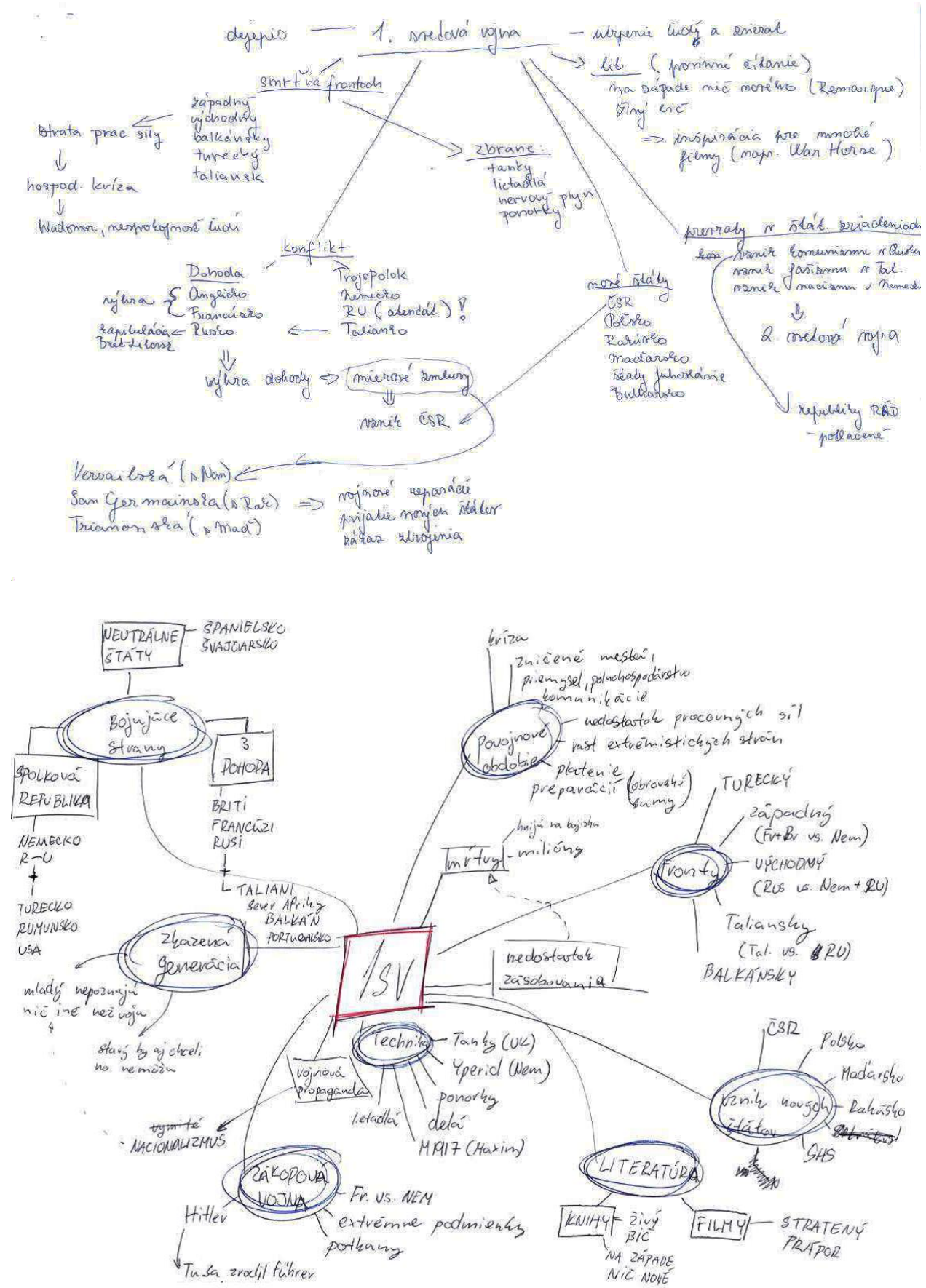

Figure 2. Examples of mind maps 


\section{Acta Technologica Dubnicae \\ volume 6, 2016, issue 2}

\subsection{Research results}

In the research, we focused on the relation level of learning style preference and the students' mental representation of the curriculum content by means of mind mapping. The research was carried out in November - December 2014, in the school building during history lessons.

In relation to the aim of the research which was focused on finding the relation level of learning style preference by learners and their mental representation of the curriculum content, our objective was to learn about the ability of students to interpret the mental representation of the curriculum content of a selected thematic field of a social science subject - history - by means of a mind map. The stated field of research focuses on a relational research problem; therefore, we used chi-square test of independence for the evaluation of our finding. We came to the following conclusions:

For the first stated supposition, "We suppose that responsibility as a factor of learning style influences the mental representation reflected in the consistency of a mind map", we examined two statistic signs, whereby we achieved an orientation image of their dependence by organization of the gathered data in a two-dimensional table. In the heading, we indicated the variants of one sign and in a legend the variants of the second sign. In the individual fields of the table, we indicated the frequency of combinations from the variants of both signs. The last line of the table represents the column sums of empirical frequencies and the last column of the table represents the line sums of empirical frequencies. In the right bottom corner of the table we indicated the total number (sum) of observations.

Chi-square test of independence was used for proving our statements, assumed by hypothesis 0 , that following features are independent, an alternative hypothesis 1 was the supposition which presupposed the dependence of following features. In order to make judgments on whether the empirical frequencies are or are not against the hypothesis $\mathrm{HO}$ on independence of both features, the so called expected frequencies were necessary to construct. These frequencies were contained in the table in case of independence of the following frequencies.

Our testing criteria were counted as follows: $\chi^{2}=\sum \frac{(O-E)^{2}}{E}$

If our counted value is lower than the table value, the zero hypothesis is assumed to be valid. In case the counted value is higher than the table value, the alternative hypothesis is valid. 


\section{Acta Technologica Dubnicae \\ volume 6, 2016, issue 2}

Table 3

Factors of responsibility and mind map consistency

\begin{tabular}{|cccc|cccccccc|}
\hline cons. & $\mathbf{1}$ & $\mathbf{2}$ & $\mathbf{3}$ & $\mathbf{4}$ & $\mathbf{5}$ & $\mathbf{6}$ & $\mathbf{7}$ & $\mathbf{8}$ & $\mathbf{9}$ & $\mathbf{1 0}$ & \\
\hline $\mathbf{0}$ & 0 & 1 & 1 & 2 & 2 & 2 & 2 & 2 & 0 & 1 & 13 \\
\hline $\mathbf{1}$ & 4 & 11 & 9 & 12 & 10 & 17 & 13 & 10 & 6 & 10 & 102 \\
\hline & 4 & 12 & 10 & 14 & 12 & 19 & 15 & 12 & 6 & 11 & 115 \\
\hline
\end{tabular}

\begin{tabular}{|ccc|}
\hline to 5 & above 5 & \\
\hline $\mathbf{6}$ & 7 & 13 \\
\hline $\mathbf{4 6}$ & 56 & 102 \\
\hline $\mathbf{5 2}$ & 63 & 115 \\
\hline to 5 & above 5 & \\
\hline $\mathbf{8 . 0 2 6 0 8 7}$ & 4.973913 & \\
\hline $\mathbf{6 2 . 9 7 3 9 1}$ & 39.02609 & 0.000266 \\
\hline
\end{tabular}

The feature "factor or responsibility" and the feature of "consistency" were independent. We created a table of empirical frequencies, thanks to which we could see in several cells that the frequencies are lower than 5 . Therefore, we reduced the number of columns and lines in the table and counted the expected frequencies for the reduced table. We counted the value of the testing criterion 0.000266. This value is lower than the one from the table (3.84). The test showed that the there is no dependence between the tested features.

By means of data analysis, we focused on the finding whether the factor of responsibility influences the consistency of a mind map. We came to the conclusion that the learning style of a student in the factor of responsibility does not influence the mental representation reflected in the consistency of a mind map. 
Table 4

Factor of task structuring and quality of hierarchies

\begin{tabular}{|ccccccccccccccc|}
\hline hier. & $\mathbf{0}$ & $\mathbf{1}$ & $\mathbf{2}$ & $\mathbf{3}$ & $\mathbf{4}$ & $\mathbf{5}$ & $\mathbf{6}$ & $\mathbf{7}$ & $\mathbf{8}$ & $\mathbf{9}$ & $\mathbf{1 0}$ & $\mathbf{1 1}$ & $\mathbf{1 3}$ & \\
\hline $\mathbf{0}$ & 0 & 1 & 0 & 4 & 3 & 1 & 1 & 0 & 1 & 1 & 0 & 0 & 0 & 12 \\
\hline $\mathbf{1}$ & 4 & 6 & 7 & 7 & 9 & 14 & 20 & 14 & 8 & 6 & 6 & 1 & 1 & 103 \\
& & & & & & & & & & & & & & \\
\hline & 4 & 7 & 7 & 11 & 12 & 15 & 21 & 14 & 9 & 7 & 6 & 1 & 1 & 115 \\
\hline
\end{tabular}

\begin{tabular}{|ccc|}
\hline to 6 & to $\mathbf{1 3}$ & \\
\hline $\mathbf{1 0}$ & 2 & 12 \\
\hline $\mathbf{6 7}$ & 36 & 103 \\
\hline $\mathbf{7 7}$ & 38 & 115 \\
\hline to 6 & to 13 & \\
\hline $\mathbf{7 . 4 0 8 6 9 6}$ & 4.591304 & \\
\hline $\mathbf{6 3 . 5 9 1 3}$ & 39.4087 & 0.091578 \\
\hline
\end{tabular}

In Table 4 we tested Supposition 2, "We suppose that task structuring as a factor of learning style influences the mental representation reflected in the quality of hierarchy".

The feature "factor of task structuring" and a feature "quality of hierarchies" were independent. We created a table of empirical frequencies thanks to which we could see that frequencies are lower than 5 in several fields of the table. We made a reduction of the columns and lines in the table and we counted the expected frequencies. We counted the value of the testing criterion 0.091578 . This value is lower than the one in the table (3.84). The test showed that there is no dependence between the tested features. Based on an analysis of the obtained data, we can state that the quality of hierarchies is not influenced by the factor of task structuring. 


\section{Acta Technologica Dubnicae \\ volume 6, 2016, issue 2}

Based on these results, we can state that suppositions 1 a 2 were not confirmed as none of the tested features - the factor of responsibility, the factor of task structuring - influenced the chosen parameter of operationalization of a mind map (consistency, quality of hierarchies).

After an overall interpretation of tables we can state that students' subjective mental representation of the curriculum content does not significantly influence their learning styles. It means that there must be a different reason for significant differences in the mind maps of students of the same year of study.

\section{Conclusions}

The aim of the research was to analyze and test the students' ability to interpret the mental representation of some curriculum content from the field of history by means of mind mapping taking into account their preferred learning styles on the selected level of education. Students in schools are not systematically prepared to be able to structure their knowledge. They have to develop the competence to create their own net of knowledge by themselves. The school environment does not take into account the individual learning styles of learners, what is more, many of them are not even able to identify them. We are aware of the fact that not every student likes learning or knowledge interpretation through mind mapping. Every human is unique, an individual with a particular learning style. Therefore, teachers - the managers of the educational process - should intend to satisfy most of their students' individual needs.

It is the teacher who can contribute to the elimination of pointless social and emotional problems related to stress arising from not understanding a topic, the difficulty of the curriculum content, from the school environment, etc. by his/her approach. Teachers can help their students by their professionalism, application of professional competencies, love to students and their teaching profession. Teachers should lead their students towards activity during the lesson, interest in classroom activities and the covered content. Only that way can students discover the unknown and to construct their own structure of knowledge. It is important for every learner to understand the covered content, to be able to connect it with prior knowledge, to work with it and to apply it into everyday life. If teachers show their learners the possibility to structure their knowledge in an easy way, they will understand the curriculum content better and not only the quality of their knowledge will increase but also their approach towards learning and the particular subject will change.

Schools are perceived as institutions with a strong impact on one's personal development and realization of one's personal potential. We think that if mental representation of content through mind mapping was used more, the knowledge 
of learners would be better structured and, therefore, working with knowledge would be easier.

This study has been written as a part of the project: APVV-15-0368 Practice in the centre of the subject field didactics, subject field didactics in the centre of preparation for practice.

\section{References}

Aushubel, D. P. (1967). Learning theory and classroom practice. In Education, Ontario: The Ontario Institute For Studies.

Bahr, S., \& Dansereau, D. (2004). Bilingual knowledge (BIK-) maps: study strategy effects. In A. J. Cañas, J. D. Novak, \& F. M. Gonzáles, (Eds.). Concept maps: theory, methodology, technology. Proceedings of the First International Conference on Concept Mapping. Pamplona, Spain: Universidad Pública de Navarra. Retrieved from http://cmc.ihmc.us/ cmc2004Proceedings/cmc2004\%20-\%20Vol\%201.pdf

Bruner, J. S. (1965). Vzdělávací proces. Praha: SP.

Buzan, T. (2007). Mentálni mapování. Praha: Portál.

Buzan, T. (2010). Mind mapping and creative thinking. Retrieved from http://destech.wordpress.com/tag/mind-maps/

Buzan, T. (2011). Myšlenkové mapy. Brno: Computer Press.

Daley, B. J. (2004). Using concept maps with adult students in higher education. In A. J. Cañas, J. D. Novak, \& F. M. Gonzáles, (Eds.). Concept maps: theory, methodology, technology. Proceedings of the First International Conference on Concept Mapping. Pamplona, Spain: Universidad Pública de Navarra. Retrieved from http://cmc.ihmc.us/cmc2004Proceedings/ cmc2004\%20-\%20Vol\%201.pdf

Dochy, F. J. (1992). Assessment of prior knowledge as a determinant for future learning. Utrecht/London: LEMMA, Jessica Kingsley.

Dochy, F. J. (1996). Prior Knowledge. In E. DeCorte \& F. E. Weinert (Eds.), International encyclopedia of developmental and instructional psychology (p. 459-464). Oxford: Pergamon.

Dunn, R., \& Dunn, K. (2002). Our philosophy and mission. Learning Styles Network. Retrieved from <http://www.learningstyles.net/n $7 \mathrm{html}>$

Dunn, R., Dunn, K., \& Price, G. E. (2004). Dotaznik stylu učení. Praha: Institut pedagogicko - psychologického poradenství ČR.

Duchovičová, J. (2010). Neurodidaktický a psychodidaktický kontext edukácie. Nitra: PF UKF.

Fenyvesiová, L. (2006). Vyučovacie metódy a interakčný štýl učitel'a. Nitra: UKF.

Fisher, R. (2004). Učíme děti myslet a učit se. Praha: Portál.

Galperin, J. P. (1980). Výber z diela. Bratislava: Psychodiagnostika. 


\section{Acta Technologica Dubnicae}

volume 6, 2016, issue 2

Glasgow, J. L., \& Papadias, D. (1992). Coputational imagery. Cognitive Science, $16,355-394$.

Hubatka, M. (2010). Myšlenkové mapy. Príklad z praxe. Moderné vyučování, 10(1). Retrieved from http://digi.modernivyucovani.cz/media/magazine/ pdf/2010_1_leden.pdf

Kaliská, L. (2008). Učebné štýly vo vzt’ahu k inteligencii, tvorivosti a školskej úspešnosti (Doctoral dissertation). Nitra: FSVaZ Nitra.

Kaliská, L. (2009). Koncepcia učebných štýlov so zameraním na teóriu D. A. Kolba. Banská Bystrica: OZ Pedagóg PF UMB.

Kosslyn, S. M. (1994). Image and brain: The resolution of the imagery debate. Cambridge, Mass: MIT Press.

Lojová, G. (2005). Individuálne osobitosti pri učení sa cudzích jazykov. Bratislava: Univerzita Komenského.

Mareš, J. (1998). Styly učeni žáků a studentů. Praha: Portál.

Mareš, J. (2001). Strukturování učiva, vyučovací a učební strategie. In J. Čáp \& J. Mareš, Psychologie pro učitele (pp. 441-472). Praha: Portál.

Mareš, J., \& Skalská, H. (1994). LSI - dotazník stylů učení pro žáky základních a středních škol. Psychológia a patopsychológia dietata , 29(3), 248-264.

Perusich, K. (2010). System diagnosis using fuzzy cognitive maps. In K. Perusich (Ed.), InTech, DOI: 10.5772/7117. Retrieved from http://www.intechopen.com/books/cognitive-maps/system-diagnosis-usingfuzzy-cognitive-maps

Petlák, E., Valabik, D., \& Zajacová, J. (2009). Vyučovanie - mozog - žiak. Bratislava: IRIS.

Riding, R., \& Rayner, S. (2009). Cognitive styles and learning strategies. London: David Fulton Publish.

Swan, J. (1997). Using cognitive mapping in management research: Decisions about technical innovation. British Journal of Management, 8(2), 183-198. DOI: http://dx.doi.org/10.1111/1467-8551.0050

Tassel, G. V. (2010). Neural pathway development. Practical classroom applications of current brain research. Retrieved from http://www.brains.org/path.htm

Thagard, P. (2001). Úvod do kognitivni védy : mysl a myšlení. Praha: Portál.

Turek, I. (2002). Učebné štýly a rozvoj schopnosti žiakov učit’ sa. Banská Bystrica: Metodicko - pedagogické centrum.

Wong, A. K. C., Lu, S. W., \& Rioux, M. (1989). Recognition and shape synthesys of 3-D objects based on attributed hypergraphs. IEEE Transactions on Pattern Analysis and Machine Intelligence 2(3), 279-289.

Zatková, T. (2011). Inteligencie a učebné štýly žiakov - predpoklad optimalizácie edukačného procesu. In E. Petlák et al., Kapitoly zo súčasnej edukácie. Bratislava: IRIS. 